\title{
充填鋼管コンクリート構造の短柱から長柱まで連続した設計式の提案 PROPOSAL OF UNIFIED AND SIMPLIFIED DESIGN METHOD FOR CONCRETE-FILLED STEEL TUBE IN SHORT COLUMN TO SLENDER COLUMN
}

\author{
佐 藤孝典* \\ Takanori SATO
}

\begin{abstract}
Recently concrete filled-steel tube (CFT) columns have been applied to hundreds buildings in Japan because of the high performance for seismic load. But the current design method of AIJ is difficult to be understood for structural designers and is discontinuous for slenderness. In this paper the unified and simplified design method is proposed. It is based on the concept of generalized cumulative strength of SRC for any slenderness with modification of the boundary condition of member. The accuracy has checked by reported experimental data.
\end{abstract}

Keywords : concrete filled-steel tube, short column, slender column, generalized cumulative strength, buckling 充填鋼管コンクリート構造，短柱，長柱，一般化累加強度，座屈

1.はじめに

充填鋼管コンクリート構造（以下, CFT構造という）は構造物の 柱部材として近年頻繁に採用されている。しかしながら，現行の鉄 骨鉄筋コンクリート構造計算規準・同解説 ${ }^{1}$ （以下, SRC規準とい う）やコンクリート充填鋼管構造設計施工指針 ${ }^{2)}$ (以下, CFT指針と いう)では，短柱と長柱の設計法が全く異なっており，その連続性 についても不明快である，短柱は一般化累加強度という全塑性酎力 を基本に組み立てられているのに対し，長柱は安定限界に基づく部 材耐力を基本に組み立てられている。CFT指針2)は，短柱部分ではコ ンファインド効果を盛り込み、長柱部分では座屈耐力を見直し，物 理現象を忠実に反映するという意味ではSRC規準りを大幅に改善した ものとなっている。しかしながら，実務者が日常の設計作業で使用 するにはあまりにも煩雑である。

そこで，本論文では実用面に主眼を置き，短柱から長柱まで連続 した概念で算定できる簡潔明暸な設計式を提案する，基本的には， 短柱の断面酎力, 具体的には一般化累加強度の概念で組み立てる. これは軸力-曲げモーメント関係（以下，NM関係という）が中立軸 位置 $(X n)$ を媒介変数として簡単に描けるからである. 節点移動の 有無に応じた設計上の終局状態を考慮し，材端の境界条件に依存し ない断面酎力を求め，それぞれの終局状態に忠実な部材耐力を提案
し，既往の実験結果を用いてその精度を検証する。また，座屈長さ ( Lk )についても実現象に則したものとする.

\section{2. 終局状態}

部材の終局状態はその役割，機能によって規定されるべきであ る．柱材の第1の機能は鉛直力を支持することである，図1に，偏心 圧縮実験了ににおける材中央の塑性ヒンジ断面の典型的なNM関係を示

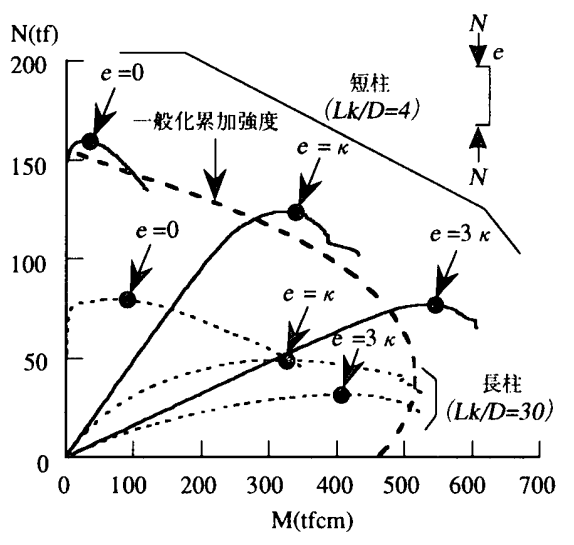

図1偏心圧縮実験による材中央点のNM関係3)

\footnotetext{
* 清水建設侏技術研究所 主任研究員・工博 Senior Researcher, Institute of Technology, Shimizu Corporation, Dr. Eng.
} 
す。この曲げモーメントには軸力とたわみによって生じる付加曲げ モーメントが含まれている，短柱の代表として座屈長さ断面せい比 が $L_{k} / D=4$ の場合，長柱の代表として座屈長さ断面せい比が $L_{k} / D=30$ の場合, それぞれ偏心距離を断面の核半径 $(\kappa)$ の0倍, 1 倍, 3倍と したものである。終局状態を軸耐力の最大点（下降開始点，

「」）とすれば，短柱はすべて一般化累加強度（全塑性酎力）に 達しているが，長柱はすべて達していない。これが短柱と長柱の根 本的な相違である。

図2に，一定軸力下における水平加力実験4での柱脚の塑性ヒンジ 断面の典型的なNM関係を示す．試験体は長柱の代表として座屈長さ 断面せい比が $L k / D=24$, 軸力比 $N / N 0=0.4$ の場合である．実験終了ま で一定軸力は保持され，図1の偏心圧縮の場合のような終局状態は見 い出せない. 図3に，その荷重-変形関係を示す，柱材の第2の機能と して水平力に対して抵抗することが挙げられる。これより，終局状 態は水平酎力の最大点（下降開始点，「○」）と規定する.
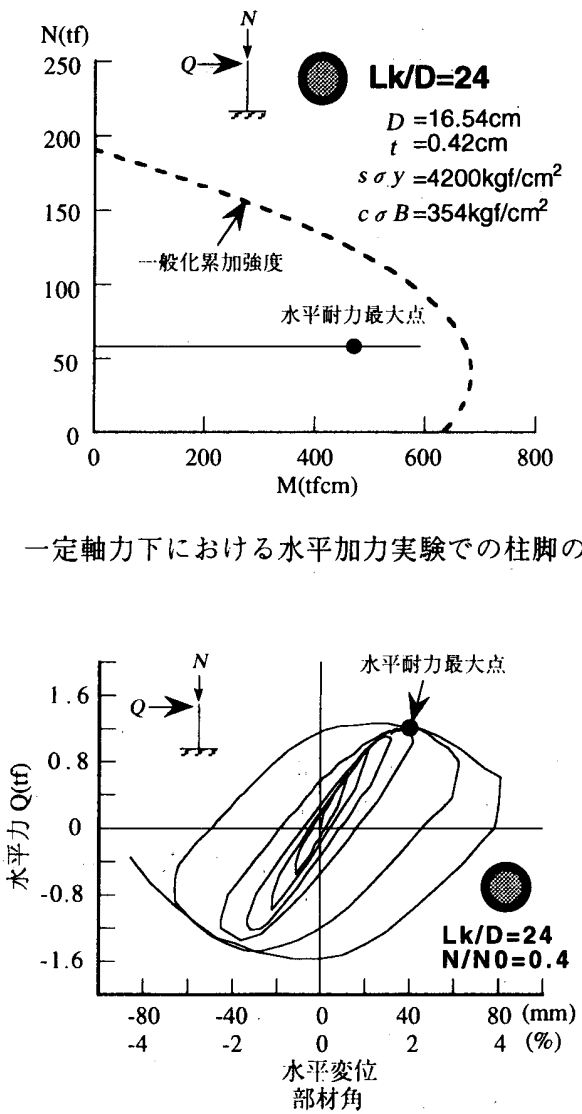

図3 一定軸力下における水平加力実験での荷重-変形関係

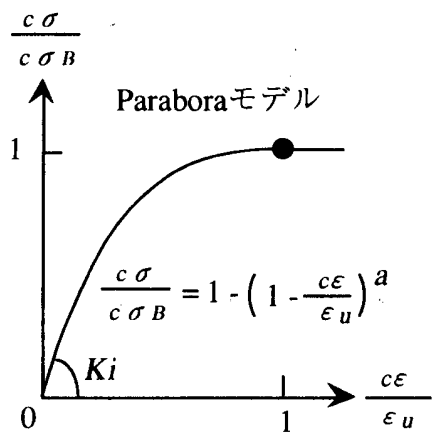

図4 コンクリートの応力-ひずみ関係
これら2つの異なる終局状態を採用する限り，両者を同一の概念で 設計式を構築することは不可能である. そこで, 前者は節点移動の 無い荷重状態に, 後者は節点移動の有る荷重状態に集約して以下論 を進める。

\section{3. カラムカーブ}

両端ピン支持された柱の中心圧縮強度つまり座屈強度は, 座屈長 さ断面せい比 $\left(L_{k} / D\right)$ に応じて低下する。 カラムカーブは, 座屈強 度 $(c \sigma c r, s \sigma c r)$ を材料強度 $(c \sigma B, s \sigma y)$ で徐した低隇率 $(c R c r, s R c r)$ と座屈長さ断面せい比の関係である. CFT指針2)で は，コンクリート柱は図4のようなParaboraモデルを用いて, Tangent Modulus法で求めた座屈強度が与えられら), 鋼管柱の座屈強度は鋼構 造塑性設計指針6)（以下，塑性設計指針という）を引用し，CFT柱の カラムカーブはそれらを単純累加したもので，式(1)で表わせる.

$$
N_{c r}={ }_{c} A \cdot c \sigma B^{*} c R c r+s A \cdot s \sigma y \cdot s R c r
$$

ただし，Ncr：CFT柱の座屈強度

$$
\begin{gathered}
c A, s A: \text { :コンクリートの断面積と鋼管の断面積 } \\
c \sigma B, s \sigma y: \text { コンクリートの圧縮強度と鋼管の降伏強度 } \\
c R c r, s R c r: \text { コンクリートの低隇率と鋼管の低減率 }
\end{gathered}
$$

図5, 図6に，CFT指針 ${ }^{2)}$ の座屈強度式を用いて, 円形断面と角形断 面についてコンクリート柱のカラムカーブと鋼管柱のカラムカーブ を示す。コンクリート強度 $(\mathrm{c} \sigma B)$ が $300 \mathrm{kgf} / \mathrm{cm}^{2}, 600 \mathrm{kgf} / \mathrm{cm}^{2}, 900 \mathrm{kgf} /$ $\mathrm{cm}^{2}$ の場合を示すが，ほとんど相違ない，鋼管降伏強度 $(s \sigma y)$ が $3000 \mathrm{kgf} / \mathrm{cm}^{2}, 4000 \mathrm{kgf} / \mathrm{cm}^{2}$ の場合を示すが，強度により異なる。それ

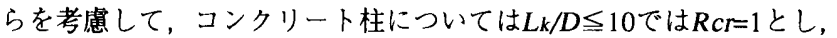

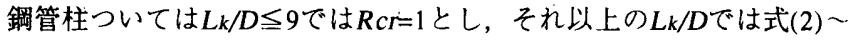
式(5)で低減させるBi-linear型の簡便な式を提案する。

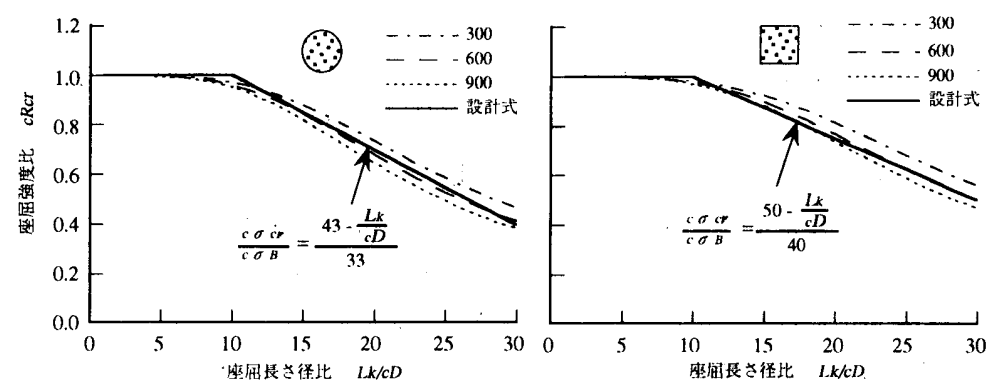

図5 コンクリート柱のカラムカーブ

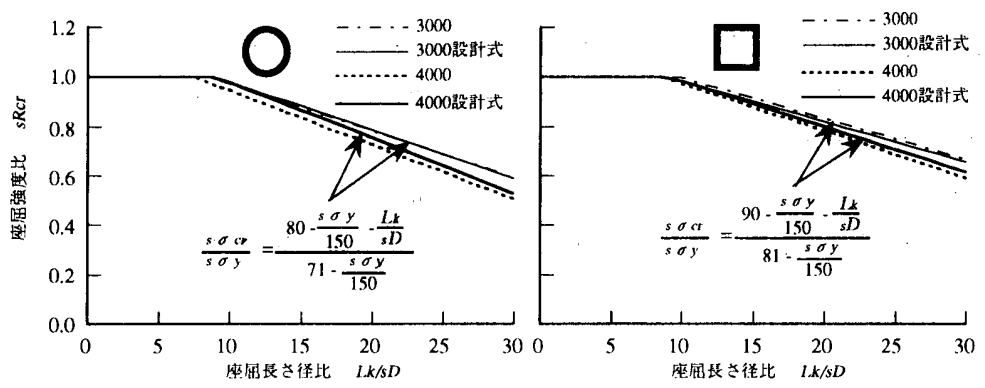

図6 鋼管柱のカラムカーブ 


$$
\begin{aligned}
& \begin{array}{l}
\text { 円形コンクリート： } c R c r=\frac{c \sigma c r}{c \sigma B}=\frac{43-\frac{L k}{c D}}{33} \cdots \cdots(2) \\
\left(10<\frac{L k}{c D}<30\right)
\end{array} \\
& \text { 角形コンクリート： } c R c r=\frac{c \sigma c r}{c \sigma B}=\frac{50-\frac{L k}{c D}}{40} \cdots \cdots \text { (3) } \\
& \left(10<\frac{L k}{c D}<30\right) \\
& \begin{array}{l}
\text { 円形鋼管 : }{ }_{s R c r}=\frac{s \sigma c r}{s \sigma y}=\frac{80-\frac{s \sigma y}{150}-\frac{L k}{s D}}{71-\frac{s \sigma y}{150}} \\
\left(9<\frac{L k}{s D}<30\right)
\end{array} \\
& \begin{array}{l}
\text { 角形鋼管 : } s R c r=\frac{s \sigma c r}{s \sigma y}=\frac{90-\frac{s \sigma y}{150}-\frac{L k}{s D}}{81-\frac{s \sigma y}{150}} \\
\left(9<\frac{L_{k}}{s D}<30\right)
\end{array} \\
& \text { ただし, } c \sigma c r, \mathrm{~s} \sigma \mathrm{cr} \text { ：コンクリートと銅管の座屈强度 }\left(\mathrm{kg} / \mathrm{cm}^{2}\right) \\
& c D, s D ： \text { コンクリートの径（幅）と鋼管の径（幅) } \\
& L k \text { : 柱の座屈舆さ }
\end{aligned}
$$

\section{4. 断面耐力}

想定する終局状態が異なるために，部材酎力は節点移動の有無で 場合分けされる. その両者の元になる断面酎力をここで提案する. この断面耐力は塑性ヒンジ断面におけるものであり，材端拘束の影 響を受けないものである，短柱から長柱まで連続的に扱うために， その断面耐力は座屈長さ断面せい比の関数となる.

図1の偏心圧縮実験から分かるように座屈長さ断面せい比が大きく なると，その酎力は全塑性耐力よりもはるかに小さくなる。そし て, 図5, 図6のカラムカーブからも座屈耐力は座屈長さ断面せい比 に応じて小さくなる．文献7)では，鉄骨構造ではあるが一定軸力下に おける片持ち柱の水平耐力の数值解析を行い, 細長比 $(\lambda)$ が 0.3 以 下（ほほ $L_{k} / D \leqq 9 に$ 相当）の短柱ではひずみ硬化が顕著で全塑性耐力 を上回るが, 細長比 $(\lambda)$ が1.0前後（ほほ $L k / D \doteqdot 30 に$ 相当）の長柱 になると図1の偏心圧縮実験と同様に全塑性酎力よりもはるかに小さ くなっている。このように，いずれの終局状態であっても断面耐力 は座屈長さ断面せい比に応じて小さくなる.

長柱の酎力は安定限界であるので, 材料の応力-ひずみ関係に依存 する.したがって，十分細長い長柱の断面酎力は材料の応力-ひずみ 関係で接線剛性が急激に低下開始するときであり，いわゆる最外縁 降伏耐力 (MAS,NAS) と考えられる。一方，十分太短い短柱の断面 耐力はコンファインド効果を考慮した全塑性酎力 $(M u, N u)$ と考え られる。つまり，CFT柱の断面耐力は座屈長さ断面せい比に応じて 最外縁降伏耐力と全塑性耐力の間にある。その際，図7に示すよう

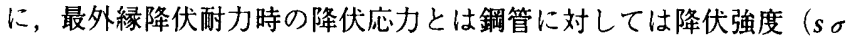
y），コンクリートに对しては臨界強度に相当する圧縮強度の $85 \%$ $(0.85 c \sigma B)$ とし, 全塑性酎力時の塑性応力とは円形断面の場合はコ ンファインド効果を考慮したもので8), 表1に示す.

そして，NM関係でのコンクリートと鋼管の累加は，最外縁降伏耐 力の場合であっても計算上の簡便さを優先させて中立軸を共有した 一般化累加強度方式とする．最外縁降伏時にはコンクリートの $0.85 \mathrm{c}$ $\sigma B$ と鋼管の $s \sigma y$ が同時に起きることにしている，これは，図8の応 力ーひずみ関係から分かるように，実務で頻繁に用いられる材料強度 領域（コンクリートは $300 \mathrm{kgf} / \mathrm{cm}^{2} \sim 900 \mathrm{kgf} / \mathrm{cm}^{2}$, 鋼管は $3000 \mathrm{kgf} / \mathrm{cm}^{2}$

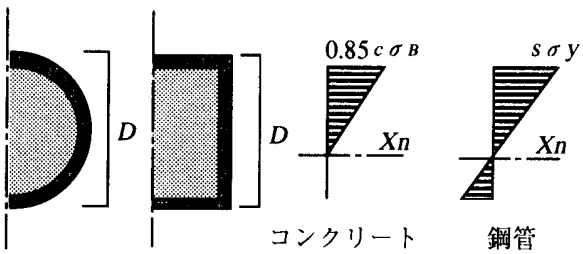

\begin{tabular}{|c|c|c|c|}
\hline & 最外縁降伏耐力時 & \multicolumn{2}{|l|}{ 全塑性酎方時 } \\
\hline & 円形断面角形断面 & 円形断面 & 角形断面 \\
\hline $\begin{array}{c}\text { コンクリート } \\
\text { 強度 }\end{array}$ & $0.85 c \sigma B$ & $0.85 c \sigma B+1.2 \frac{2 t}{D-2 t} s \sigma y$ & $0.85 c \sigma B$ \\
\hline 鋼管強度 & $s \sigma y$ & $0.82 s \sigma y$ (压) $-1.12 s \sigma y$ (引 & $s \sigma y$ \\
\hline
\end{tabular}

最外縁降伏耐力 $\left(M_{A S}, N_{A S}\right)$ の)応力分布

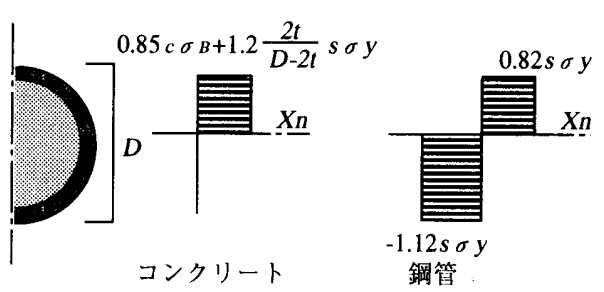

全塑性酎力 $(M u, N u)$ の応力分布 (刑形断面)

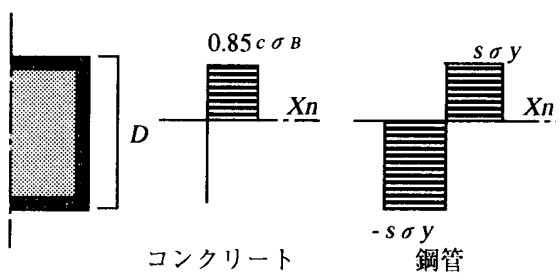

全塑性耐力 $(\mathrm{Mu}, \mathrm{Nu})$ の㐫力分布（伯形断面）

図7 断面酎力の応力分布

表1 各耐力時の材料強度

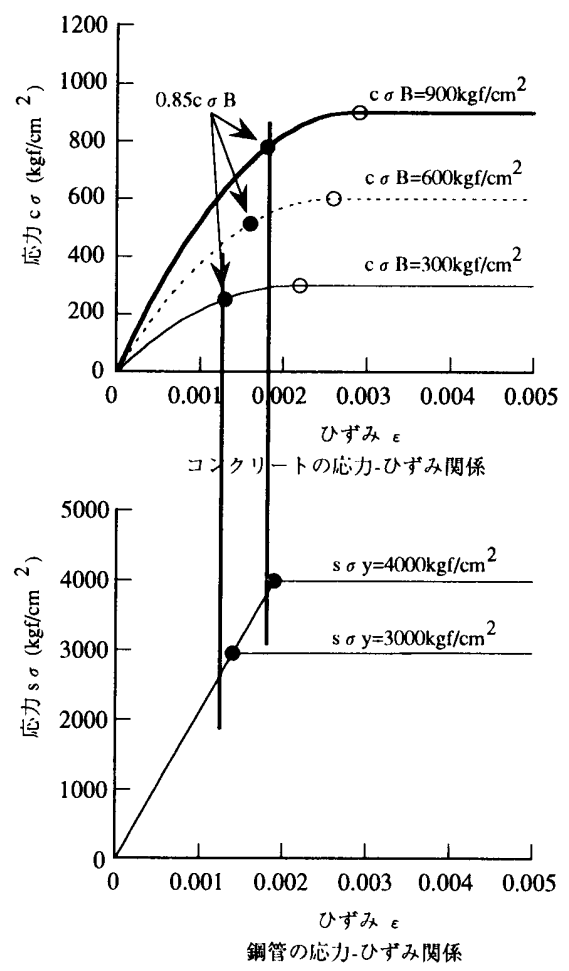

図8 最外縁降伏時の応力-ひずみ関係 
～4000 kgf $\left./ \mathrm{cm}^{2}\right)$ ではほほ平面保持されており，実用上遜色ないと判 断したからである。

そこで，座屈長さ断面せい比に応じた断面酎力（Mucr,Nucr）は, 図9に示すように，同一の中立軸位置における最外縁降伏耐力点 $(M A S, N A S)$ と全塑性酎力点 $(M u, N u)$ を $R c r^{3}:\left(1-R c r^{3}\right)$ に内分す る点とする。これは既往の偏心压縮実験結果9),10)と合うように決めた ものである。その際，最外縁降伏耐力（MAS,NAS）は全塑性耐力 $(\mathrm{Mu}, \mathrm{Nu})$ を縮小して曲げ酎力最大值が一致するようにしたもので 代用し，低隇率（Rcr）はコンクリートの場合と鋼管の場合の加重平 均をとる.そして, 従来の設計式(6),11),12),133)どと同様に軸耐力の項に はカラムカーブによる低減率を乗じる。すると，次式のように表わ せる.

$$
\begin{aligned}
& M u c r=R c r^{3} \cdot M u+\left(1-R c r^{3}\right) \cdot M A S \\
& N_{u c r}=\left(R c r^{3} \cdot N_{u}+\left(1-R c r^{3}\right) \cdot N_{A s}\right) \cdot R_{c r} \cdots \cdots(7)
\end{aligned}
$$

ただし，MucI，Nucr：座屈長さ断面せい比に応じた断面耐力

$M u ， N_{u}$ : コンファインド効果を考虑した全塑性耐力（CFT指針 2)答照） MAS，NAS：最外縁降伏粉力（SRC規準1)参照）

$R c r ：$ 加重平均した低隇率 $(\mathrm{Ncr} / \mathrm{Nu})$

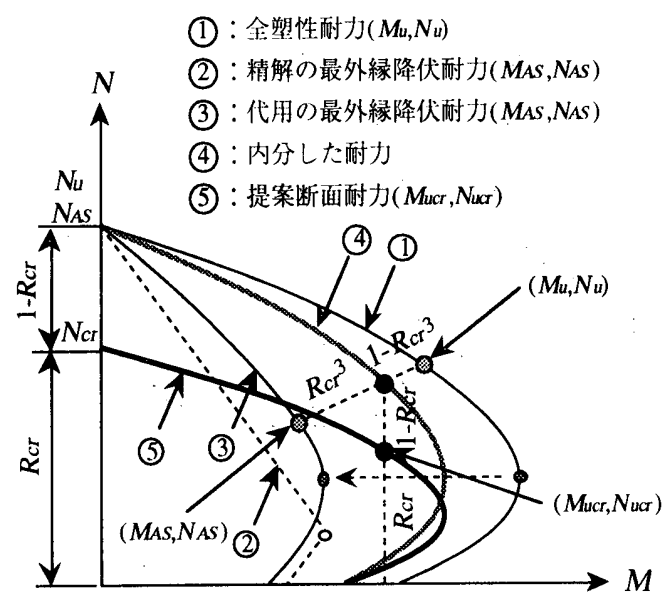

図9座屈長さ断面せい比に応じた断面酎力（角形CFTの場合）

\section{5. 部材耐力}

\section{1 節点移動の無い場合}

節点移動の無い場合とは, 重量倉庫等で偏載荷重が作用する場合 に該当する，図10に示すように，材端の軸力と曲げモーメントによ り部材途中に大きな付加曲げモーメントが発生し，そこに塑性ヒン ジが出来て安定限界に達する。こ れが各国の鋼構造設計規準類6),11) ,12),14),15),16)などで採用されている基 本的な終局状態である。

塑性設計指針6)では，ある軸力 における弾性曲げ釣り合い方程式 の理論解を導き，式(8)に示すよう に，ある軸力における断面耐力に モーメント拡大係数の逆数を乗じ て，材端曲げ耐力を求めている。 ここで, モーメント拡大係数の逆

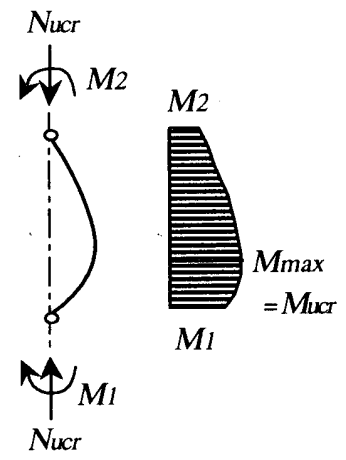

図10 節点移動が無い場合
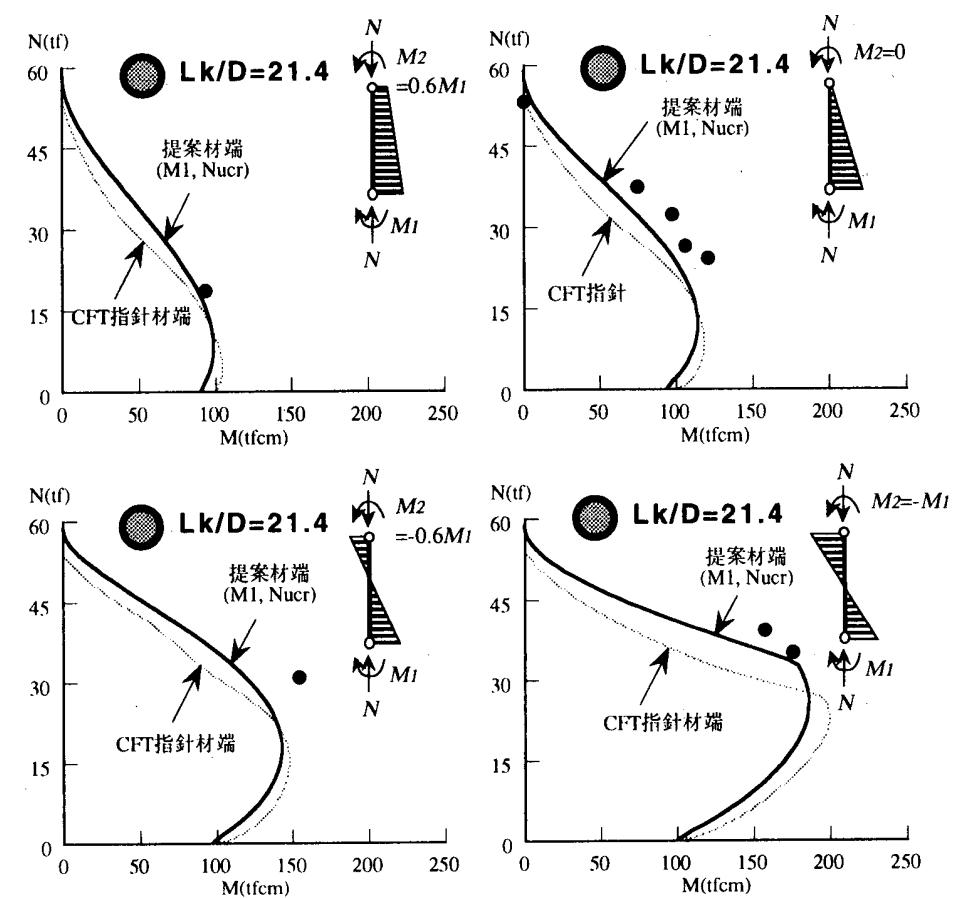

図11 節点移動が無くモーメント勾配のある実験結果との比較 
コンクリート強度 $\mathrm{c} \sigma B=979 \mathrm{~kg} \mathrm{f} / \mathrm{cm}^{2}$, 鋼管引張降伏強度 $s \sigma$ $y=4180 \mathrm{kgf} / \mathrm{cm}^{2}$, 座屈長さ断面せい比 $L k / D=21.4$ である。モーメント勾 配が $M 2 / M 1=0.6,0.0,-0.6,-1.0$ について，CFT指針2)とよく似た曲線を 描き， CFT指針 ${ }^{2}$ よりも実験結果に近い。

さらに，文献9),10)に示された偏心圧縮実験結果を用いて，図12お
よび図13でCFT指針2)とともに比較する。図12は円形断面のCFTで, 直径 $D=16.52 \mathrm{~cm}$, 板厚 $t=0.408 \mathrm{~cm}$, コンクリート強度 $c \sigma B=417 \mathrm{kgf} / \mathrm{cm}^{2}$, そして鋼管降伏強度についてはCFT指針2)には文献9), 10)どおり圧縮 降伏強度 $s \sigma y=3600 \mathrm{kgf} / \mathrm{cm}^{2}$ を用い, 本提案には引張降伏強度 $s \sigma$ $y=4220 \mathrm{kgf} / \mathrm{cm}^{2}$ を用いる。 また, 図13は角形断面のCFTについても同
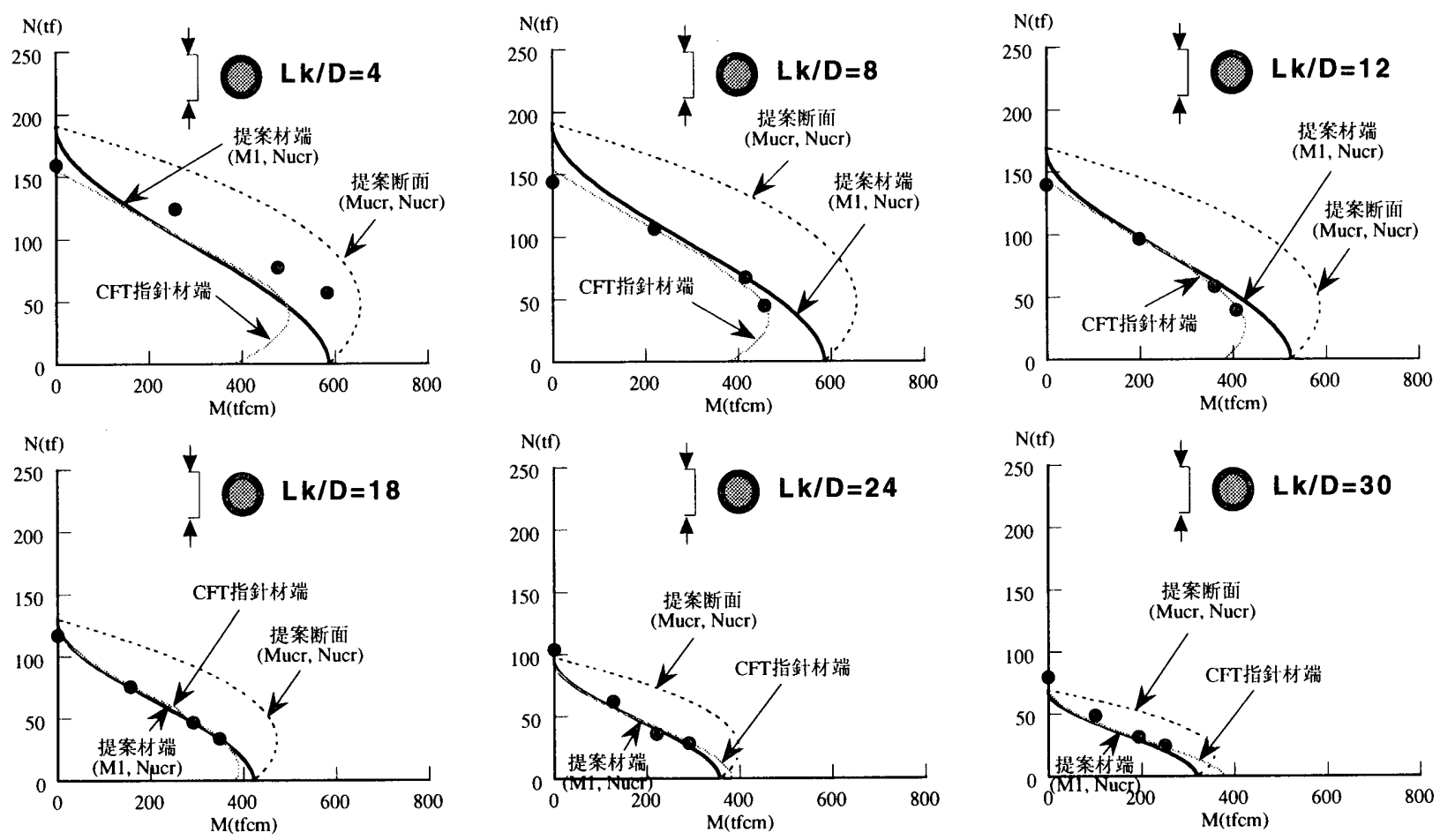

図12 偏心圧縮実験結果との比較（円形）
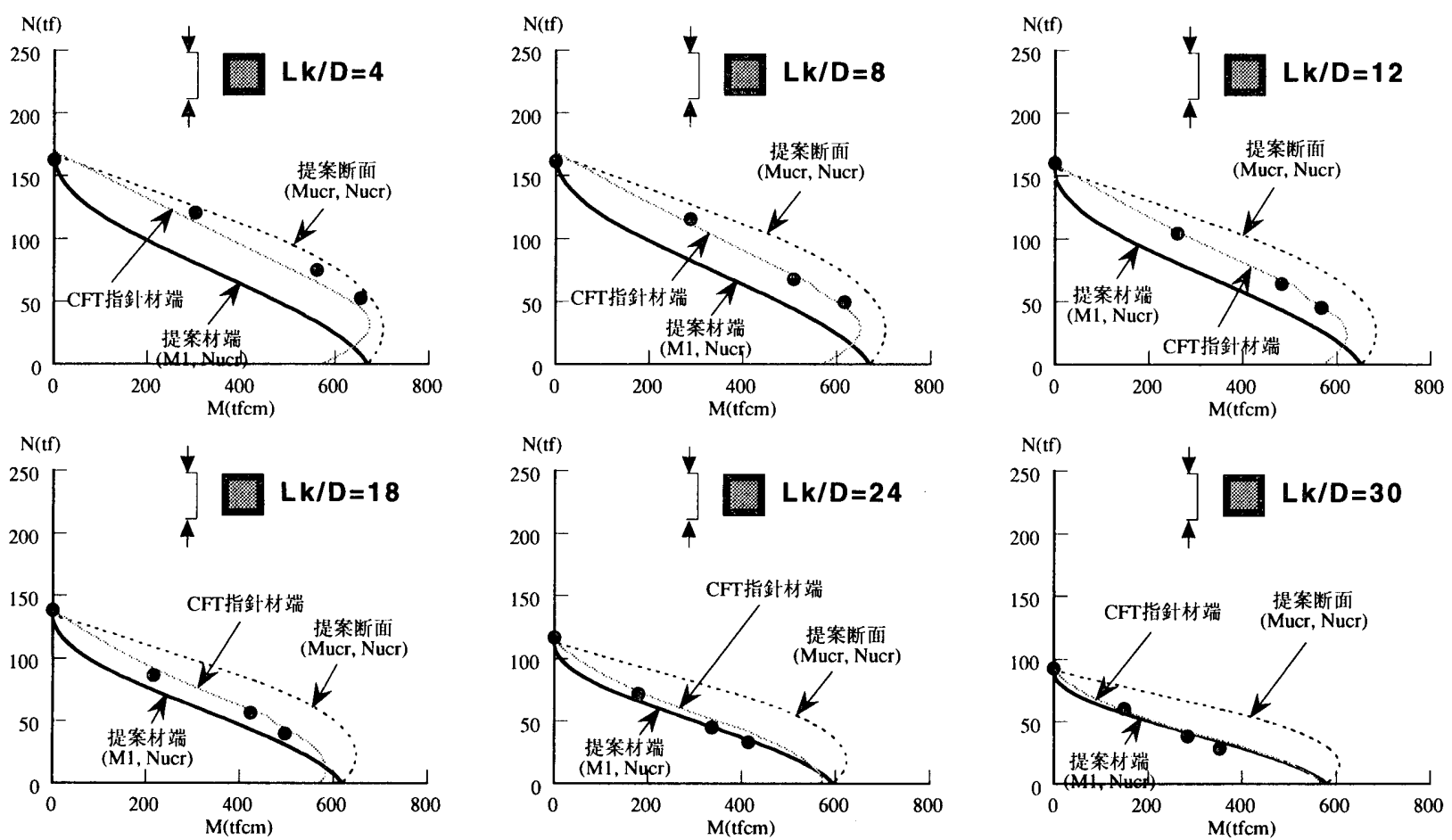

図13偏心圧縮実験結果との比較（角形） 
様に; 幅 $D=14.98 \mathrm{~cm}$, 板厚 $t=0.427 \mathrm{~cm}$, コンクリート強度 $c \sigma B=325 \mathrm{kgf} /$ $\mathrm{cm}^{2}$, 鋼管降伏強度についてはCFT指針2)には压縮降伏強度 $s \sigma$ $y=4200 \mathrm{kgf} / \mathrm{cm}^{2}$ を用い，本提案には引張降伏強度 $s \sigma y=4470 \mathrm{kgf} / \mathrm{cm}^{2}$ を 用いる。図中に，参考として提案する断面耐力も描く。いずれも， 座屈長さ断面せい比を $L_{k} / D=4,8,12,18,24,30$ としたものである. 円形断面の場合はCFT指針2) と同様に実験結果と極めて酷似してい る. 角形断面の場合は実験結果の下限を押さえており，破壊性状が 脆性的であることを考慮すると妥当である。 また，提案式のNM関係 は軸力0の純曲げ酎力が座屈長さ断面せい比 $\left(L_{k} / D\right)$ とともに小さく なるのが特徵である。これは文献19)にも採用されているが，多くの 従来の設計式6),11),12),13)なととと異なる。

\section{2 節点移動の有る場合}

節点移動の有る場合とは，実際は地震荷重が作用する場合に該当 する. 軸力上りも水平力（水平変位）が支配的で, 柱が破壊すると きは必ず柱頭もしくは柱脚に塑性ヒンジが出来る．柱先行降伏型構 造では柱耐力は層全体の耐力となり, 梁先行降伏型構造では柱酎力 は柱梁の耐力比を照査する際に用いられる。したがって，前節のよ うな軸力の安定限界に基づくのではなく，水平酎力の最大点（下降 開始点）を終局状態と規定する。これは，従来の設計規準類6),11),12) 14),15),16)などでは節点移動の無い場合と同じ終局状態で, 式(8)で $C_{M=1}$ として扱っているのと大幅に異なっている.

本来，設計上の部材耐力は軸力とたわみによって生じる付加曲げ モーメントを差し引いた材端耐力であることが好ましい：それにつ いては, 曲げモーメント-変位関係のモデル化が必要なので今後の課 題とし，ここでは付加曲げモーメントを含む材端酎力を提案する.

図14に示すように，梁や接合部等の材端拘束により補強されて材
端近傍の断面耐力は増大し, 外力の曲げモーメントとの比較で塑性 ヒンジ位置が材端からずれる，そのずれ長さを考慮した部材耐力と して式(12)を提案する。なお，ずれ長さ ( LX ) は軸力比 (Nucr/ $N c r)$ の関数として式(13)で表わされ， $L k / D=6$ のとき文献18)の提案 式と連続するようにしている，柱梁の耐力比を照査するときは，通

$$
M i=\frac{L}{L-L X} M u c r+\frac{L X}{L-L X} M 2
$$

ただし，形断面の場命は，

$$
L x=\left(1.5\left(\frac{N_{u c r}}{N_{c r}}\right)^{2}+0.5\right) \frac{L}{6}-
$$

伯形断面の場合は, $L X=0.5 D$

M1, Nucr：塑性ヒンジ端の曲げモーメントと軸力の終局耐力の組合せ M2：非破壊端の曲げモーメント，ただし複曲率をの場合を正

$L, D:$ 柱の節点間長さと径

$L x:$ 塑性ヒンジの材端からのずれ長さ

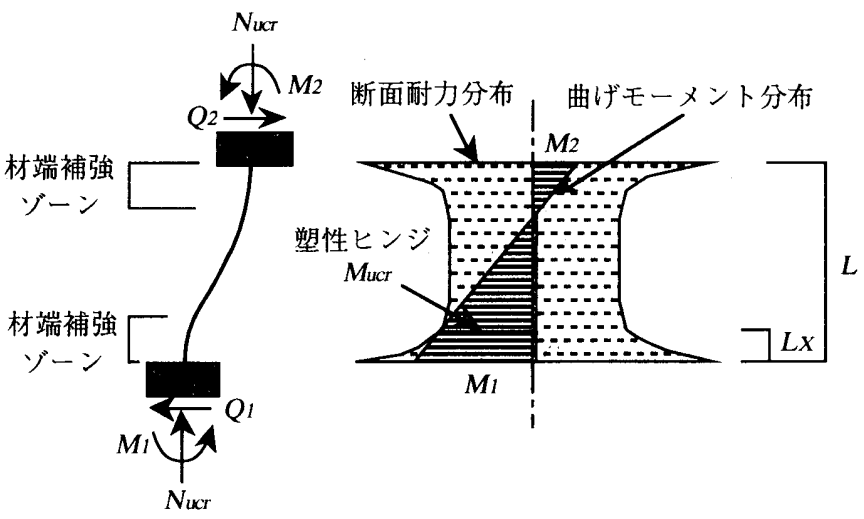

図14 断面耐力分布と塑性ヒンジ発生断面
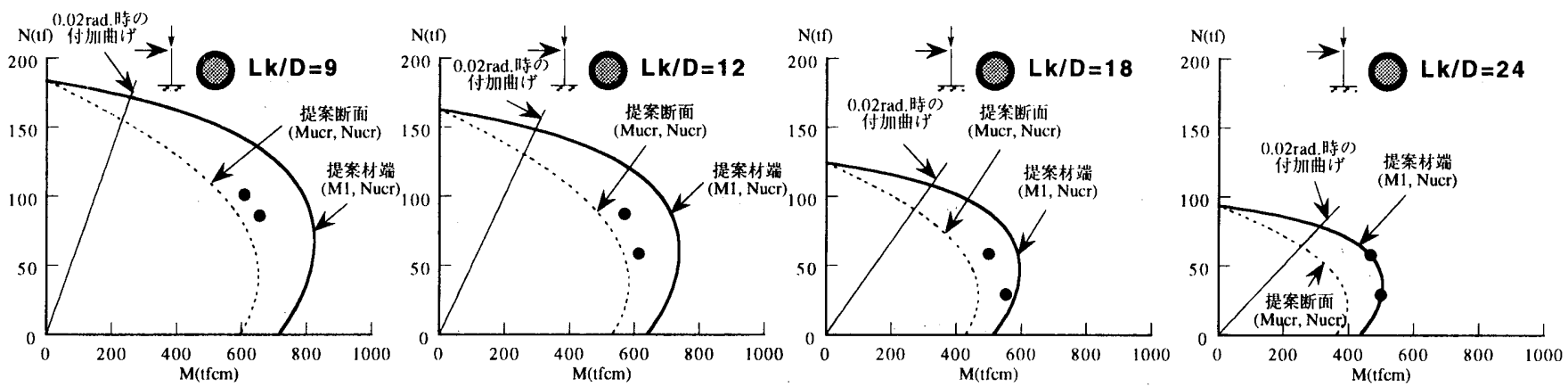

図15 水平加力実験結果との比較（円形）
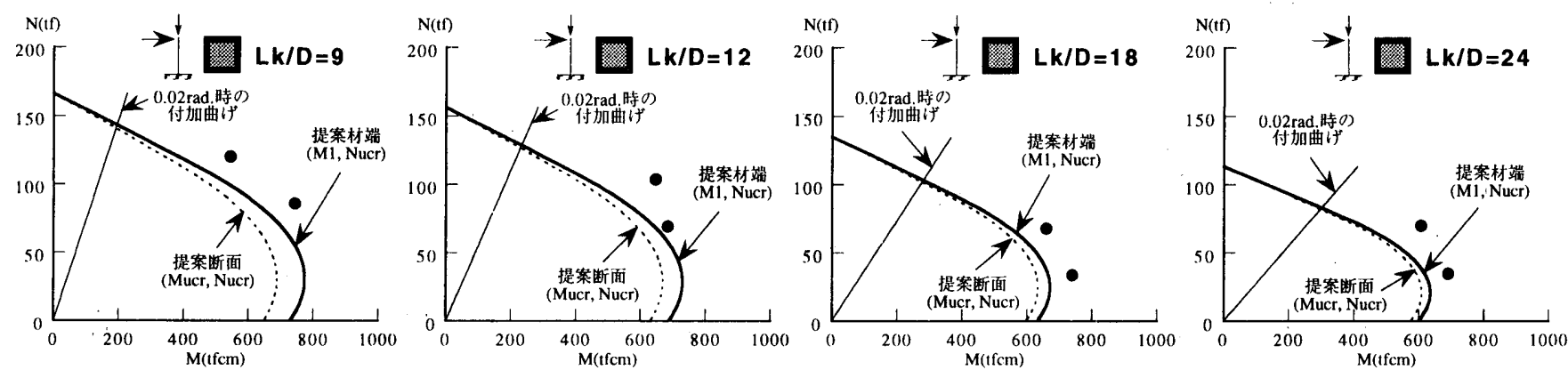

図16 水平加力実験結果との比較 (角形) 
常の柱梁の弾性剛比に応じた $M 2 / M 1$ の比を式(12)に用いる. 柱先行降 伏型構造での柱耐力を求めるときは，崩壊メカニズムが形成される $M_{l}=M_{2}$ の逆対称荷重状態の場合を想定して式(12)を用いる.

文献4)に示された一定軸力下における水平加力実験を用いて，図 15 おび図16で実験結果と比較する. 図15は円形断面のCFTで, 直 径 $\mathrm{D}=16.54 \mathrm{~cm}$, 板厚 $\mathrm{t}=0.42 \mathrm{~cm}$, 鋼管引張降伏強度 $s \quad \mathrm{y}=4200 \mathrm{kgf} / \mathrm{cm}^{2}$, ב ンクリート強度 $\mathrm{c} \sigma \mathrm{B}=354 \mathrm{kgf} / \mathrm{cm}^{2}$ である。また，図16は角形断面の $\mathrm{CFT}$ で, 幅 $\mathrm{D}=15.06 \mathrm{~cm}$, 板厚 $\mathrm{t}=0.44 \mathrm{~cm}$, 鋼管引張降伏強度 $\mathrm{s} \sigma$ $\mathrm{y}=4120 \mathrm{kgf} / \mathrm{cm}^{2}$, コンクリート強度 $\mathrm{c} \sigma \mathrm{B}=354 \mathrm{kgf} / \mathrm{cm}^{2}$ である．提案值お よび実験結果はすべて付加曲げモーメントを含む材端酎力で比較検 討する．図中に，参考として提案する断面酎力も描く．

提案する材端酎力は, 円形断面では実験結果の中央, 角形断面で は実験結果の下限を押さえている。これは，円形断面の破壊性状は 勒性があり，角形断面の破壊性状は脆性的であることを考慮すると 妥当である，ただし，図3からも分かるとおり，最大点の部材角は $2 \%$ 3\%にも達する。

\section{6. 座屈長さ}

柱梁の節点で柱端，梁端のいずれに塑性ヒンジが出来るかは，構 造物全体の構造性能に大きく影響する，CFT指針2)では，節点移動が 無いときは座届長さは柱長さ以下となるので，座屈長さを柱長さ $\left(L_{k}=L\right)$ とすれば安全側となるが, 節点移動が有る場合は座屈長さ は柱長さ以上となるので, 座屈長さは柱や梁の剛度に応じた複雑な 計算をすることになる.

しかしながら，節点移動が有る場合でも柱先行降伏型構造なら，
塑性ヒンジは必ず柱頭または柱脚に発生し，明らかに座屈長さは柱 長さ $(L k=L)$ としてよい，その際，当然のことながら，付加曲げ モーメントを考慮した外力で評価する必要がある．また，節点移動 が有る梁先行降伏型構造では, 柱耐力は柱梁の耐力比を照查する際 に用いられる。この場合, 梁が降伏した後でもその降伏曲げモーメ ントに抵抗しつつ軸力を支持していることを確かめる必要がある。

図17に示すように，柱梁の剛比に応じて計算した座屈長さ $\left(L_{k}\right)$ の区間には水平変位と軸力による付加曲げモーメント $((N L+\Delta N) \delta / 2)$ と柱梁接合部から梁降伏曲げモーメント $(B M y)$ が入力されている。我 が国の通常の設計では，層間変形角は高々 $\mathrm{R}=0.02 \mathrm{rad}$. 程度で，これに ようて生じる付加曲げモーメントを図15および図16のNM関係に描 く。すると，座屈強度に対する軸力比 $(\mathrm{N} / \mathrm{Ncr})$ が円形断面では約 0.85 以下，角形断面では約 0.75 以下であれば，付加曲げモーメントよ りも梁降伏曲げモーメントが確実に大きくなる。したがって，柱の 耐力は柱梁接合部で算定しておけば良いので，座屈長さは柱長さ $(L k=L)$ としてよいことになる，ただし，それを越える大きな軸力 が作用する場合は, 従来どおり柱梁の剛比に応じた座屈長さ $(L k)$ を用いて，軸力の安定限界が終局状態となることもある。ささらに， 図17に示すように，地震荷重を受けて水平移動と軸力の圧縮および 引張が同時に生じる場合，引張側柱は破壊せずに，破壊しようとす る圧縮側柱を拘束する。したがって，節点移動が無い状態になり， 結果的に座屈長さは柱長さの 0.6 倍 $(L k=0.6 L)$ まで短くすることが できる場合もあるという実験的かつ解析的報告がある20)，以上をま とめると，表2のようになる。

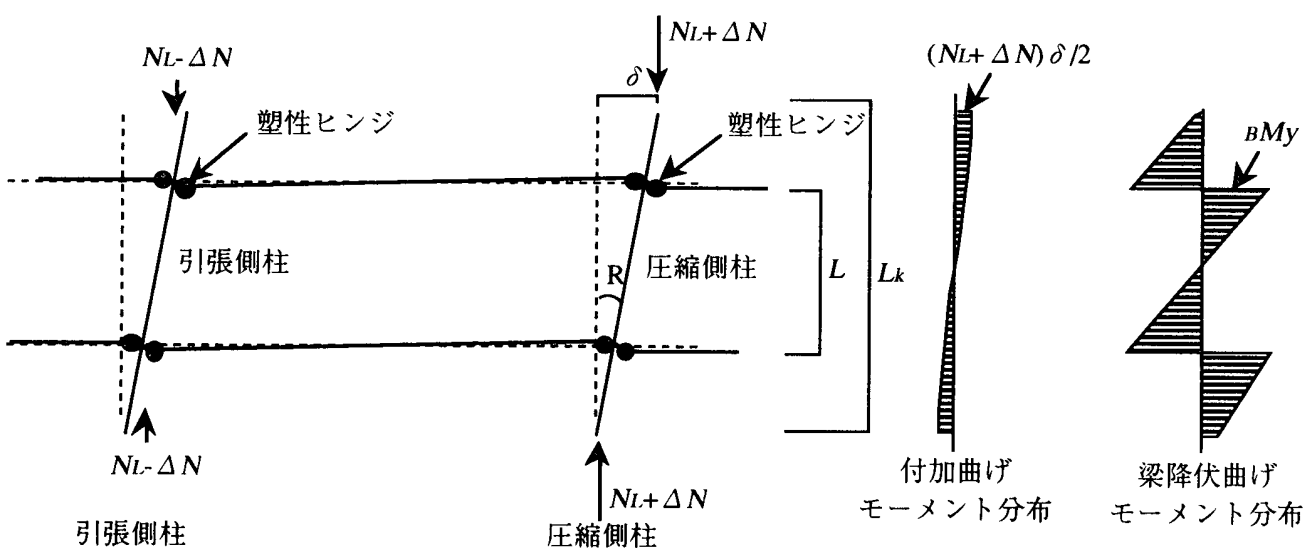

圧維側柱のモーメント分布

図17＼cjkstart節点移動が有り梁先行降伏型構造の終局状態

表2＼cjkstart崩壊モードと座屈長さおよび終局状態

\begin{tabular}{|c|c|c|c|c|}
\hline & 崩壊モード & 座屈長さ（ $\left.\boldsymbol{L}_{\boldsymbol{k}}\right)$ & 終局状態 & 算定式 \\
\hline \multirow{2}{*}{ 節点移動無 } & 柱先行降伏型 & \multirow{2}{*}{$L k=L （$ 柱長さ） } & \multirow{2}{*}{ 軸力の安定限界 } & \multirow{2}{*}{ 式 (10)，式（11） } \\
\hline & 梁先行降伏型 & & & \\
\hline \multirow{3}{*}{ 節点移動有 } & 柱先行降伏型 & $L k=L$ （柱長さ） & 水平力の最大点 & 式 (12), 式 (13) \\
\hline & \multirow[b]{2}{*}{ 梁先行降伏型 } & $L_{k}=L$ （柱長さ） & 水平力の最大点 & 式 (12), 式 (13) \\
\hline & & $\begin{array}{l}L k \text { Lk,CFT指針により } \\
\text { 柱梁の剛比で算定 }\end{array}$ & 軸力の安定限界 & 式 (10), 式 (11) \\
\hline
\end{tabular}




\section{7. まとめ}

現行のCFT構造の柱の設計式が短柱と長柱で異なり不連続であ ク，実務者にとってあまりにも煩雑であるので，本論文では実用面 に主眼を置いた簡単で連続性のある設計式を提案した。

カラムカーブを式(2)〜式(5)のような簡単な式とし，従来のSRC規 準で使い慣れた一般化累加強度による座屈長さ断面せい比に応じた 断面耐力を式(6)および式(7)で与えた。そして，節点移動の有無に よって異なる終局状態を規定し，短柱から長柱まで連続している部 材耐力を提案した．節点移動が無い場合は従来の安定限界に基づく 式を修正した式(10)および式(11)，節点移動が有る場合は塑性ヒンジ の位置を考虑した式(12)および式(13)を提案した。これらを既往の実 験結果と比較したところ（図11～図13，図15～図16参照），破壊性 状を考慮して円形断面の場合は中央、角形断面の場合は下限という 工学的判断より提案式は妥当であることを示した。また，座屈長さ についても崩壊モードごとに区別したものを表2に提案した。

\section{謝辞}

本論文の作成に当たり，九州大学教授松井千秋博士，同助教授津 田恵吾博士には，貴重な実験デー夕を提供して戴き，深く感謝の意 を表します。

\section{参考文献}

1)日本建築学会：鉄骨鉄筋コンクリート構造計算规集・同解説, 1987.6 2)日本建築学会：コンクリート充填鋼管構造設計施工指針, 1997.10

3) C. Matsui, K. Tsuda and Y. Ishibashi : Slender Concrete Filled Steel Tubular Col- umns under Combined Compression and Bending, Structural Steel, 4 PSSC, Vol.3.Steel-Concrete Composite Structures, pp.29-36, 1995

4)美野英司，松非千秋、津田惠吾，有働文久：軸力と曲げせん断を受けるコンク リート光填鋼管長柱の座屈設計法に関する研究, 日本建築学会大会学術講演 梗概集 (近畿)，pp.965-966, 1996.9

5) 津田恵吾，松井千秋：シンクリート允填鋼管柱の累加座屈荷重，龬構造論文 集, 第3巻第9号, pp.11-18, 1996.3

6)日本建築学会：鋼構造塑性設計指針，pp.114-129，1975.11

7)中島正愛，山脇克彦，辻文三：鉄骨柱材の耐力に関する感度分析，日本建築学 会大会学術講演梗概集 (中国)，pp.1453-1454，1990.10

8)住藤孝典'：充填鋼管コンクリート柱の部材耐力の提案（せん断スパン比を $\mathrm{M}$ QDを考虑した部材耐力），日本建築学会大会学術講演梗概集（関東）， pp.913-914, 1997.9

9) 松井千秋，津时恵吾，尾崎功，石橋靖夫：コンクリート充填鋼管長柱の耐 力，日本建築学会構造系論文集，第494号, pp.137-144, 1997.4

10)津田恵吾，松非千秋，石橋靖夫：コンクリート立填鋼管長柱の酎力評価式 日本建築学会構造系諭文集; 第496号, pp.119-126, 1997.6

11) European Committee for Standardization, Eurocode 4(draft) : Design of Composite Steel and Concrete Structures, 1992

12) American Institute of Steel Construction : Load and Resistance Factor Design Specification for Structural Steel Building, CHAPTER 1, September 1986

13)鐘善淘：鋼管混凝土結枸，黒竟江科学技術出版社，1994.10

14)日本建築学会：鋼管蛬造設計施工指針，1990.1

15)日本建築学会：龬構造座萤設計指針，1996.1

16) 日本建築学会：銅構造限界状態設計規準（案）－同解説、1990.2

17) 津田恵吾, 松井千秋, 藤永隆：モーメント公配のあるコンクリート充填鋼管 長柱の耐力について，日本建築学会九州支部研究報告，pp.497-500，第37 号, 1998.3

18）佐藤孝典：立填鋼管コンクリート構造における鋼とコンクリートの分担力抽 出のための変形経路再現実験，日本建築学会構造系論文集，第 468 岇， pp.155-164, 1995.2

19)周ほか：鋼管混凝土結构設計・施工手冊，中国建築工業出版社，1991

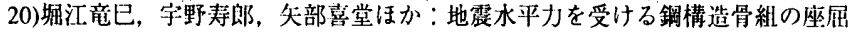
実験（その2，解析による検討），日本建築学会大会学術講演梗概集（中 国），pp.1389-1390，1990.10

(1999年2月10日原稿受理，1999年 7 月13日採用決定 